\title{
Endoscopic negative pressure therapy (ENPT) for duodenal leakage - novel repair technique using open-pore film (OFD) and polyurethane-foam drainages (OPD) $D$
}

\section{다)(i) $(5)$}

\author{
Authors \\ Institutions \\ 1 Marienkrankenhaus - Department for General, \\ Abdominal, Thoracic and Vascular Surgery, Hamburg, \\ Germany, Hamburg \\ 2 Westküstenklinikum Heide - Department for Internal \\ Medicine, Gastroenterology, Hemato-Oncology, \\ Nephrology and Endocrinology, Heide, Schleswig- \\ Holstein, Germany \\ 3 HELIOS Frankenwaldklinik Kronach - Department of \\ Gastroenterology \\ Kronach, Bayern, Germany
}

Gunnar Loske ${ }^{1}$, Frank Rucktaeschel ${ }^{2}$, Tobias Schorsch ${ }^{1}$, Klaus Moenkemueller ${ }^{3}$, Christian Theodor Mueller ${ }^{1}$ submitted 20.3.2019

accepted after revision 21.6.2019

\author{
Bibliography \\ DOI https://doi.org/10.1055/a-0972-9660 | \\ Endoscopy International Open 2019; 07: E1424-E1431 \\ (c) Georg Thieme Verlag KG Stuttgart · New York \\ eISSN 2196-9736
}

\section{Corresponding author}

Gunnar Loske, Katholisches Marienkrankenhaus Hamburg gGmbH, Department for General, Abdominal, Thoracic and Vascular Surgery, Alfredstrasse 9, Hamburg 22087,

Germany

Fax: +00494025461400

loske.chir@marienkrankenhaus.org

\section{ABSTRACT}

Background and study aims Endoscopic negative pressure therapy (ENPT) is used to close transmural defects in the rectum and esophagus. Very few reports have described ENPT to manage duodenal defects. This study was designed to demonstrate ENPT in a population of $11 \mathrm{pa}$ tients with transmural duodenal leakages.

Patients and methods The method of ENPT was adapted for duodenal use. Open-pore polyurethane-foam or a thin, open-pore double-layered film was wrapped around the distal end of a gastroduodenal tube. First, this open-pore element was placed on the inner wound in the duodenum with endoscopy. Second, continuous negative pressure of $-125 \mathrm{mmHg}$ was applied with an electronic pump. Drains were changed after 2 to 7 days.

Results Eleven patients were treated with duodenal leaks. Eight defects occurred after operative closure of perforated duodenal ulcers, papillectomy or stricturoplasty, one anastomotic leakage after Billroth - 1 distal gastric resection, one iatrogenic perforation in endoscopic retrograde cholangiopancreatography, and one by a surgical drain. Median duration of therapy was 11 days (range $7-24$ days). Complete healing of defects was achieved in all patients.

Conclusion ENPT is an innovative endoscopic alternative for treatment of transmural duodenal defects.

\section{Introduction}

Intestinal leakage is often associated with critical illness due to septic condition. The therapeutic aim is to control the septic conditions, focusing on closing the intestinal defect and establishing sufficient drainage [1]. Endoscopic procedures are of increasing importance in management of intestinal defects [2 -4].

Initially, negative pressure wound therapy was developed to treat superficial infected wounds. Subsequently intracorporal endoscopic negative pressure therapy (ENPT) (also known as endoscopic vacuum therapy, E-vac therapy, and endo-vac ther-

apy) was also found to be effective in healing intracorporal wounds. ENPT was initially used to treat anastomotic insufficiencies in the rectum [5], and was subsequently adapted to treat esophageal leakages [6]. To date, more than 200 patients with transmural defects of the esophagus (anastomotic leaks and perforations) have been treated with a healing rate of $90 \%$ $[7,8]$.

So far, only a few reports have described use of ENPT in cases of duodenal leakages [9-18]. In this retrospective study, we demonstrate use of ENPT in a population of 11 patients. Pertinent information on six patients already has been published in a small primary case series or first case reports [9-13]. 


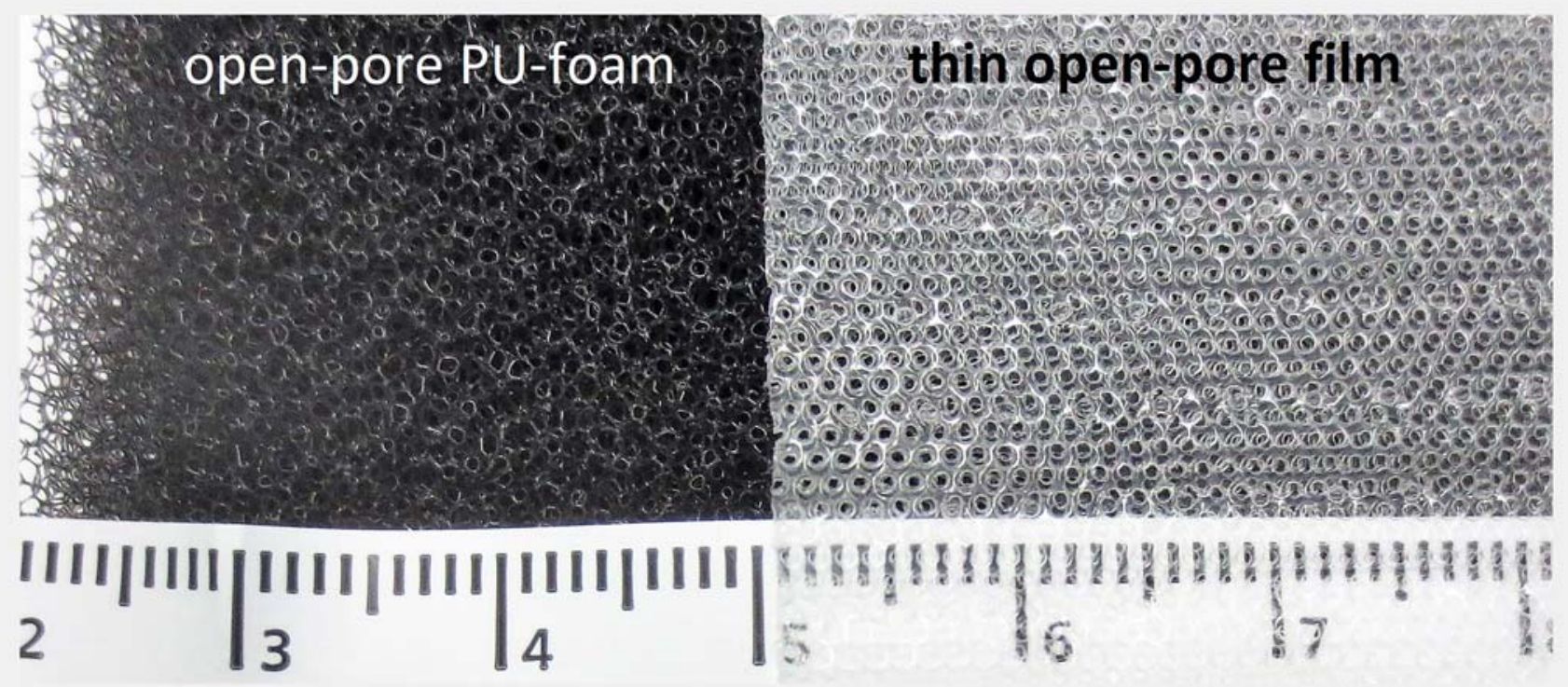

- Fig. 1 Surface of open-pore material used in ENPT. On the left: open-pore polyurethane foam characterized by densely packed and irregular pore openings. On the right: thin, double-layer, open-pore film composed of two perforated membranes with an interspace that does not collapse under suction. The surface is characterized by regular pores.

The objective of this study was to present a spectrum of endoscopic methods and introduce the novel technological developments that enabled successful adaptation of ENPT for duodenal leakages.

\section{Patients and methods}

Because there are no approved medical ENPT devices for use in the duodenum (neither for drainage nor electronic vacuum pumps), all drainage devices were self-made. To facilitate treatment in the duodenum, several new drainage types and alternative endoscopic placement techniques have been developed. These are described below. For negative pressure, we used an electronic pump for therapy on the body surface. All treatments were performed as individual healing attempts to which the patients had consented.

For ENPT in the duodenum, we use drainage tubes with an open-pore drainage element (oE). Open-pore polyurethane foams and an open-pore film are suitable for use as an oE ( $\triangleright$ Fig. 1). They are fixed around the distal end of the laterally perforated drainage tube with a suture ( $\triangleright$ Fig. 2$)[19,20]$. Both materials can be combined, in which case, the foam is coated with the film $[12,21]$.

We distinguish between an intracavitary and intraluminal method of ENPT [19]. For intracavitary ENPT, the oE of the drainage tube is placed through the transmural defect into the extraluminal cavity. For intraluminal ENPT, the oE is placed into the lumen of the intestine. Both alternatives can be combined.

Intraluminal ENPT results in occlusion of the intestinal lumen, thus sealing off the defect. Simultaneous with ENPT, duodenal and wound secretions are guided in centripetal luminal direction. Intracavitary ENPT results in closure of the defect

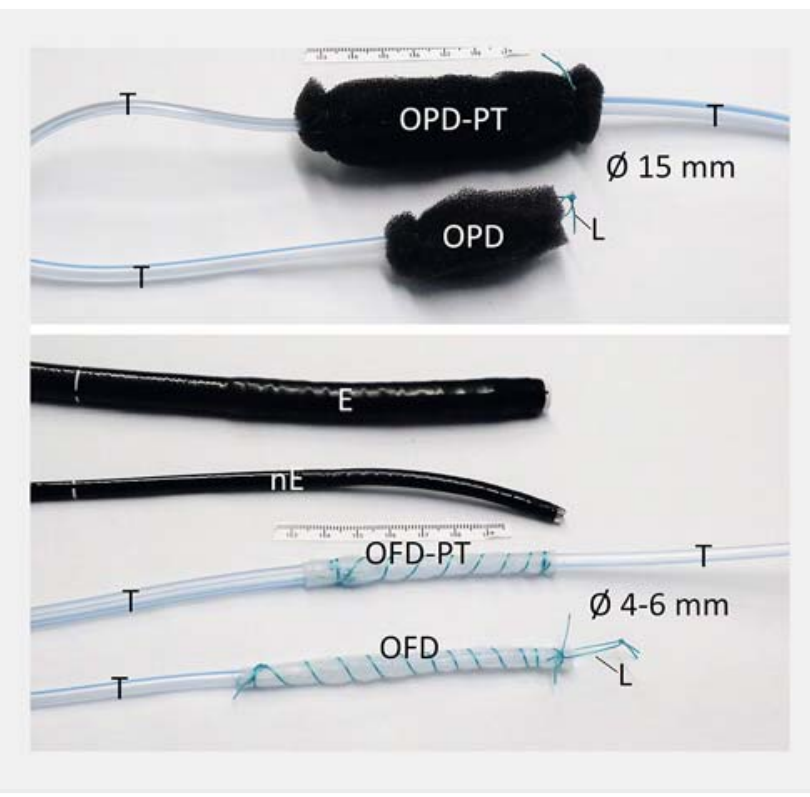

- Fig.2 Open-pore drains used in ENPT. Open-pore polyurethane foam drainage (OPD) or open-pore film drainage (OFD) fixed around the distal end of a drainage tube (T). ODP-PT and OFD-PT are used for the pull-through maneuver. The open-pore polyurethane foam or film element is placed in the middle of the tube (T). standard gastroscope (E), small-bore endoscope ( $\mathrm{nE}$ ) and loop (L), which can be grasped for the placement manoeuvre.

and drainage of extralumial the septic focus. A schematic illustrating the principle of treatment in the duodenum is shown in - Fig. 3. 


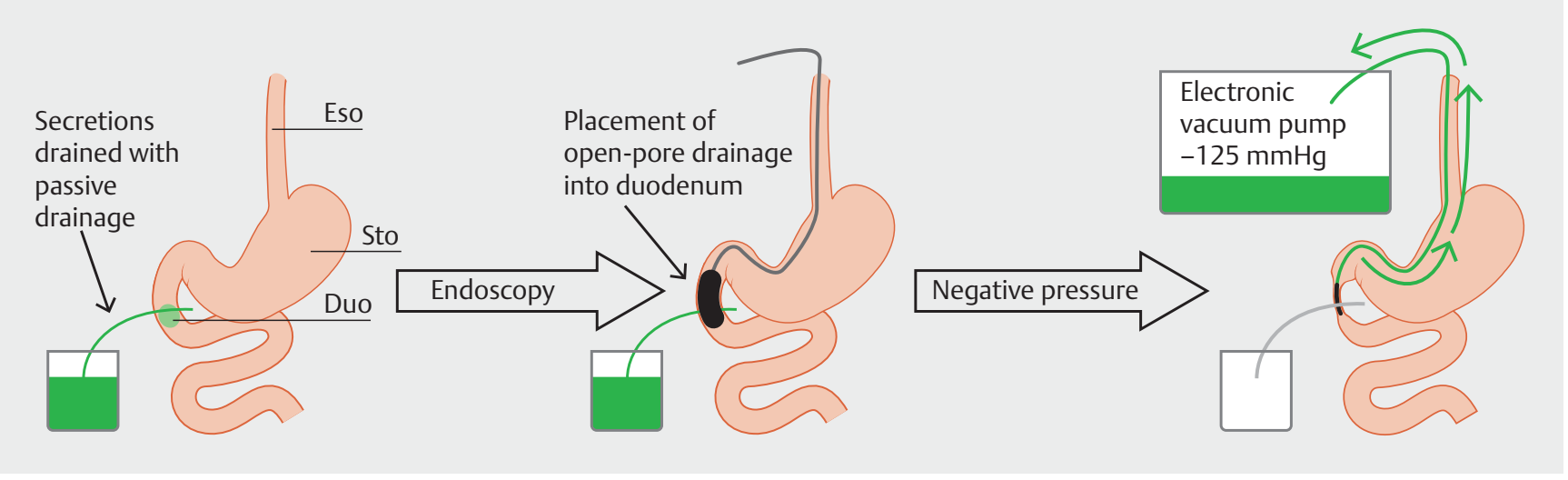

- Fig. 3 Diagram showing the principles and course of intraluminal ENPT in the duodenum. Esophagus (Eso), stomach (Sto), and duodenum (Duo) with a transmural defect. Secretions are drained through passive drainage. After endoscopic insertion of an open-pore drainage into the duodenal lumen, negative pressure is applied. This results in closure of the duodenal lumen and active drainage of duodenal secretions.

\section{ENPT with open-pore polyurethane foam drainage using endoscopic push technique for drain placement}

To construct open-pore polyurethane foam drains (OPD), we used open-pore polyurethane foams (Suprasorb CNP, Lohmann \& Rauscher International GmbH \& Co. KG, Rengsdorf, Germany, V.A.C. GranuFoam, Kinectic Concepts, Inc., San Antonio, Texas United States, Endo-SPONGE B. Braun, Melsungen, Germany) for the oE and a 120-cm nasogastric tube (Ventrol, 12-14 Ch $\times 120 \mathrm{~cm}$, Covidien ARGYLE Dublin, Ireland). The tube has lateral perforations at the tip of the distal end. The foam oE was fixed by a suture at the distal end of the tube and trimmed to a size of approximately $1.5 \mathrm{~cm}$ in diameter and 2 to $4 \mathrm{~cm}$ in length. A graspable loop was created at the distal end ( $>$ Fig. 2).

For the placement procedure, the distal end of the foam-oE was held with a tripod grasper or alternatively the loop was grasped with forceps and pulled to the distal end of the endoscope. Proper placement requires that the endoscope and drain pass the oropharyngeal curve and the upper esophageal sphincter. A short overtube was used to navigate safely down the pharynx and the upper esophageal sphincter. The anatomy is shown in > Fig. 4. The OPDs were inserted along the overtube and guided with the endoscope into the duodenum. The oE was placed intraluminally on the defect zone for intraluminal ENPT ( $\triangleright$ Fig. 3, $\triangleright$ Video). At the end the drainage tube was guided through the nose and fixed to it with a suture or plaster. The drain was connected to an electronic vacuum pump and negative pressure was applied.

\section{ENPT with OPD using endoscopic surgical rendezvous and pull technique}

In one case, the OPD was placed using a surgical rendezvous technique. During laparotomy, the defect was passed with the endoscope and the proximal end of the tube was grasped with endoscopic forceps. Then the tube was pulled intraluminally and lead out nasally. In this case, the foam-oE fixed at the distal end of the tube was placed extraluminally.

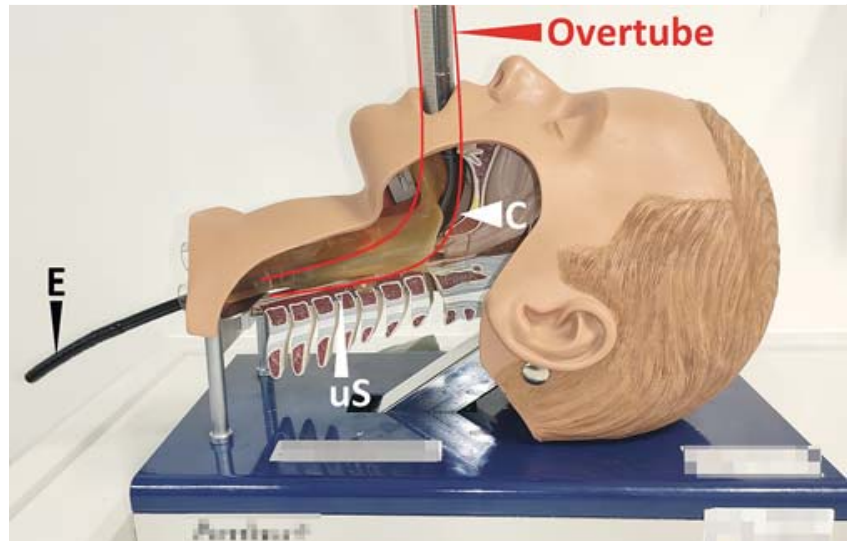

- Fig. 4 A short overtube is used to safely bypass the pharyngeal curve (C) and the upper esophageal sphincter (US). The anatomical conditions can be seen in the model. Endoscope (E).

\section{Endoscopic Negative Pressure Therapy}

in Duodenum

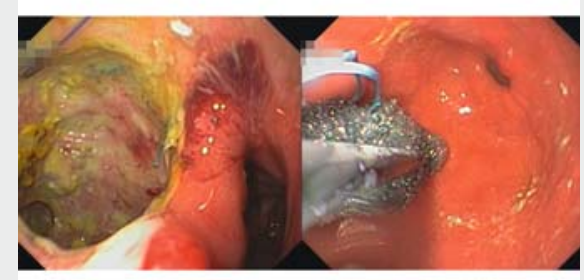

$\checkmark$ Video Demonstration of duodenal ENPT in a diagrammatic video, the course of treatment in a case of suture rupture, and the pull-through maneuver for placing an OPD. 


\section{ENPT with open-pore film drainage using endoscopic push technique for drain placement}

Novel small-bore, open-pore drainage devices for ENPT which pass through small openings have been developed ( $\mathbf{F i g . 2}$ $[11-13,20]$. They consist of a $120-\mathrm{cm}$ drainage tube (Ventrol, $12 \mathrm{Ch} \times 120 \mathrm{~cm}$; Covidien Argyle, Dublin, Ireland) and a very thin, double-layered open-pore film (Suprasorb CNP, Drainage Film; Lohmann \& Rauscher International GmbH \& Co. KG, Rengsdorf, Germany). The film is wrapped around the distal end of the tube and fixed with a suture [20]. The film-oE can either be short - just a few centimeters in length - or up to $25 \mathrm{~cm}$ or longer. At the distal end, a graspable loop is created. The openpore film drainage tube (OFD) has a diameter of only 4 to 6 millimeters. Initially the film was constructed for abdominal negative pressure treatment. It can be placed directly onto the peritoneum, intestines, and internal organs. Secretions are drained internally and through a small space between the two layers of the membrane.

The OFD placement procedure in the duodenal lumen is the same as for intestinal feeding tubes. The OFD is inserted through the nose with the small diameter of the device allowing placement through small openings. Then the tip of the drainage tube is grasped with forceps and pushed forward into the duodenal lumen under endoscopic view [11].

\section{ENPT with OPD and OFD using endoscopic pull- through technique for drain placement}

In case of a duodenal cutaneous fistula, OPDs and OFDs also can be inserted by a pull-through maneuver along the duodenal-cutaneous channel ( $\triangleright$ Video). Therefore, new types of OPD and OFD have been developed ( $\triangleright$ Fig. 2) $[12,13$, 22]. Two drainage tubes were connected at their distal ends. The open-pore foam and the open-pore film, respectively, were fixed on the middle part of the tube, wrapping the lateral perforations of the connected tubes. The oE was pulled into the fistula channel. One-half was placed through the defect into the fistula opening and the other half into the duodenal and gastric lumen. The oE was also inserted entirely into the fistula channel. Correct placement of the oE foam or film was controlled with endoscopy. The cutaneous end was blocked with a knot or a clamp. The proximal end, which passed through the nose, was connected to the vacuum device and negative pressure was applied. Secretions were directed in an intraluminal direction. To insert a new drainage tube after a treatment period lasting several days, the tube was used to pull through a new OPD/OFD device.

The majority of ENPT sessions using a pull-through technique started with OPD devices. During the course of therapy, when the channel shrank in size, the diameter of the drainage tube was gradually reduced to $4 \mathrm{~mm}$ with an OFD [11].

\section{Removal and change of OPD and OFD}

In all variants of placing methods used, drainage tubes were changed twice weekly. Then the suction was terminated and the drain was removed by simply pulling the oral end of the tube. The intracorporal wound was inspected endoscopically and, if necessary, a new OPD/OFD was positioned using the above-mentioned techniques.

ENPT was terminated when the cleaned inner wound was covered with granulation tissue or the enterocutaneous channel had shrunk to a diameter of a few millimeters. In cases involving an enterocutaneous fistula, the final session of ENPT was performed with an intraluminally placed oE covering the inner fistula opening.

\section{Negative pressure with electronic vacuum pumps}

For negative pressure application, we always used an electronically controlled vacuum pump (KCI V.A.C. Freedome, Activac, Ultravac KCI USA Inc., San Antonio, Texas, United States, setting: $-125 \mathrm{mmHg}$, continuous, highest intensity).

\section{Results}

Between 2010 and 2018, 11 patients (4 males and 7 females, aged 43 to 80 years) with transmural duodenal defects were treated with ENPT. Complete healing of the duodenal defect was achieved in all patients (100\%). Median total duration of therapy was 11 days (range 7 to 24 days). Two patients died 1 week and 1 month, respectively, after the defect was closed due to reasons not related to the endoscopic treatment. Clinical data on patients and treatment are shown in > Table $\mathbf{1}$.

In eight patients duodenal leakage occurred because of a suture rupture after surgical closure of perforated duodenal ulcers, papillectomy or stricturoplasty. In one patient a semicircular anastomotic leakage was found after gastroduodenostomy. This patient had undergone Billroth-1 resection because of a complex duodenal perforation. Surgical attempts to close the large duodenal cutaneous fistula in two relaparotomies were unsuccessful [13]. One patient had a type 2 iatrogenic perforation after endoscopic retrograde cholangiopancreatography (ERCP); that patient simultaneously underwent diagnostic laparoscopy to rule out peritonitis [11]. One patient had a transmural iatrogenic perforation defect derived from an extraluminal surgical drain placed after jejunal resection [9]. None of the patients had a perforation into the free abdominal cavity. Local tissue perfusion was uncompromised in all patients. In all cases, ENPT was applied directly after the endoscopic diagnosis.

We used the push technique to place the oE in seven patients, in two patients the push and the pull-through method, in one patient the pull-through maneuver alone and in one patient, the surgical rendezvous technique.

Seven patients were treated with OPD devices; six of them with the intraluminal alternative of ENPT. In one patient intracavitary ENPT with OPD was used. This OPD was placed via the surgical rendezvous maneuver. The foam on the tip of the drain was placed through the defect outside the duodenal lumen next to the intestinal wall. Then it was covered with the omentum majus to create a small compartment when the defect experienced suction due to negative pressure. The drain was kept in place for 11 days. After removal, a small cavity created by suction healed completely within a few days. 
- Table 1 Clinical data on endoscopic negative pressure therapy (ENPT) for transmural duodenal defects with open-pore polyurethane foam drainage (OPD) and open-pore film drainage (OFD).

\begin{tabular}{|c|c|c|c|c|c|c|c|c|}
\hline $\begin{array}{l}\text { Patient } \\
\text { age }(\mathrm{y}) \text {; } \\
\text { male } \\
(\mathrm{m}) / \mathrm{fe}- \\
\text { male (f) }\end{array}$ & $\begin{array}{l}\text { Initial diagnosis/ } \\
\text { initial surgical } \\
\text { treatment }\end{array}$ & $\begin{array}{l}\text { Type of transmural } \\
\text { defect treated }\end{array}$ & $\begin{array}{l}\text { Open- } \\
\text { pore } \\
\text { drain- } \\
\text { age } \\
\text { type }\end{array}$ & $\begin{array}{l}\text { Var- } \\
\text { iants } \\
\text { of } \\
\text { ENPT } \\
\text { used }\end{array}$ & $\begin{array}{l}\text { Endoscopic } \\
\text { technique } \\
\text { used for } \\
\text { drainage } \\
\text { placement }\end{array}$ & $\begin{array}{l}\text { Dura- } \\
\text { tion } \\
\text { (days) }\end{array}$ & $\begin{array}{l}\text { Changes } \\
\text { of open- } \\
\text { pore } \\
\text { drain } \\
\text { (number) }\end{array}$ & $\begin{array}{l}\text { Success, } \\
\text { healing of } \\
\text { duodenal } \\
\text { defect }\end{array}$ \\
\hline 43 y; M & $\begin{array}{l}\text { latrogenic perforation } \\
\text { After endoscopic dila- } \\
\text { tation of a stenosis/ } \\
\text { surgical closure with } \\
\text { suture and stricturo- } \\
\text { plasty (course of ENPT } \\
\text { is shown in video) }\end{array}$ & Suture rupture & OPD & IL & Push & 7 & 0 & Yes \\
\hline $60 y ; F[9]$ & $\begin{array}{l}\text { latrogenic perforation } \\
\text { of an operative drain }\end{array}$ & $\begin{array}{l}\text { latrogenic perfora- } \\
\text { tion }\end{array}$ & OPD & IL & Push & 7 & 1 & Yes \\
\hline $74 y ; F$ & Surgical papillectomy & Suture rupture & OPD & IL & Push & 13 & 2 & $\begin{array}{l}\text { Yes, patient } \\
\text { died } 1 \text { week } \\
\text { after end of } \\
\text { ENPT }\end{array}$ \\
\hline $64 \mathrm{y} ; \mathrm{F}$ & $\begin{array}{l}\text { Perforated duodenal } \\
\text { ulcer/ surgical closure } \\
\text { with suture }\end{array}$ & Suture rupture & OPD & IC & $\begin{array}{l}\text { Intraoperative } \\
\text { rendezvous }\end{array}$ & 11 & 0 & Yes \\
\hline $76 y ; F$ & $\begin{array}{l}\text { Perforated duodenal } \\
\text { ulcer/ surgical closure } \\
\text { with suture }\end{array}$ & Suture rupture & OPD & IC & Push & 13 & & Yes \\
\hline $80 \mathrm{y} ; \mathrm{F}$ & $\begin{array}{l}\text { Perforated duodenal } \\
\text { ulcer/ surgical closure } \\
\text { with suture }\end{array}$ & Suture rupture & OPD & IL & $\begin{array}{l}\text { Push, pull- } \\
\text { through }\end{array}$ & 11 & 3 & $\begin{array}{l}\text { Yes, patient } \\
\text { died } 1 \\
\text { month } \\
\text { after end of } \\
\text { ENPT }\end{array}$ \\
\hline $61 \mathrm{y} ; \mathrm{F}$ & $\begin{array}{l}\text { Perforated duodenal } \\
\text { ulcer/ surgical closure } \\
\text { with suture }\end{array}$ & Suture rupture & $\begin{array}{l}\text { OFD, } \\
\text { OPD }\end{array}$ & IL & Push & 19 & 3 & Yes \\
\hline $\begin{array}{l}80 \mathrm{y} ; \mathrm{F} \\
{[11]}\end{array}$ & $\begin{array}{l}\text { latrogenic perforation } \\
\text { typ } 2 \text { while ERCP/ diag- } \\
\text { nostic laparoscopy }\end{array}$ & $\begin{array}{l}\text { latrogenic perfora- } \\
\text { tion }\end{array}$ & OFD & IL & Push & 6 & 1 & Yes \\
\hline $71 \mathrm{y} ; \mathrm{M}$ & $\begin{array}{l}\text { Perforated duodenal } \\
\text { ulcer: surgical closure } \\
\text { with suture }\end{array}$ & Suture rupture & OPD & IL & Push & 11 & 2 & Yes \\
\hline $\begin{array}{l}53 y ; M \\
{[12]}\end{array}$ & $\begin{array}{l}\text { Perforated duodenal } \\
\text { ulcer/ surgical closure } \\
\text { with suture }\end{array}$ & Suture rupture & $\begin{array}{l}\text { OFD, } \\
\text { OPD }\end{array}$ & IL & Pull-through & 14 & 3 & Yes \\
\hline $\begin{array}{l}61 \mathrm{y} ; \mathrm{M} \\
{[13]}\end{array}$ & $\begin{array}{l}\text { Perforated duodenal } \\
\text { ulcer/ } \\
\text { Billroth-1 gastro-jeju- } \\
\text { nostomy }\end{array}$ & $\begin{array}{l}\text { Anastomotic leak- } \\
\text { age }\end{array}$ & $\begin{array}{l}\text { OFD, } \\
\text { OPD }\end{array}$ & $\mathrm{IL} / \mathrm{IC}$ & $\begin{array}{l}\text { Push, Pull- } \\
\text { through }\end{array}$ & 24 & 5 & Yes \\
\hline $\begin{array}{l}11 \mathrm{~Pa}- \\
\text { tients } \\
43-80 \mathrm{y} \text {; } \\
4 \times \mathrm{M} / \\
7 \times \mathrm{F}\end{array}$ & & $\begin{array}{l}8 \times \text { Suture rupture } \\
1 \times \text { latrogenic per- } \\
\text { foration }(E R C P) \\
1 \times \text { latrogenic per- } \\
\text { foration of opera- } \\
\text { tive drain } \\
1 \times \text { Anastomotic } \\
\text { leakage }\end{array}$ & $\begin{array}{l}7 \times \text { OPD } \\
1 \times \text { OFD } \\
3 \text { OPD } / \\
\text { OFD }\end{array}$ & $\begin{array}{l}9 \times I \mathrm{~L} \\
1 \times I C \\
1 \times I L / \\
I C\end{array}$ & $\begin{array}{l}7 \times \text { Push } \\
2 \times \text { Push and } \\
\text { pull-through } \\
1 \times \text { Pull- } \\
\text { through } \\
1 \times \text { Intraoper- } \\
\text { ative rende- } \\
\text { vous }\end{array}$ & $\begin{array}{l}m=11 \\
(7- \\
24)\end{array}$ & $0-5$ & $\begin{array}{l}11 / 11,2 \\
\text { patients } \\
\text { died } \\
1 \text { week/ } 1 \\
\text { month } \\
\text { after ENPT }\end{array}$ \\
\hline
\end{tabular}

ENPT (endoscopic negative pressure therapy); OPD (open-pore polyurethane foam drainage); OFD (open-pore film drainage); IL (intraluminal); IC (intracavitary); ERCP (endoscopic retrograde cholangiopancreatography) 

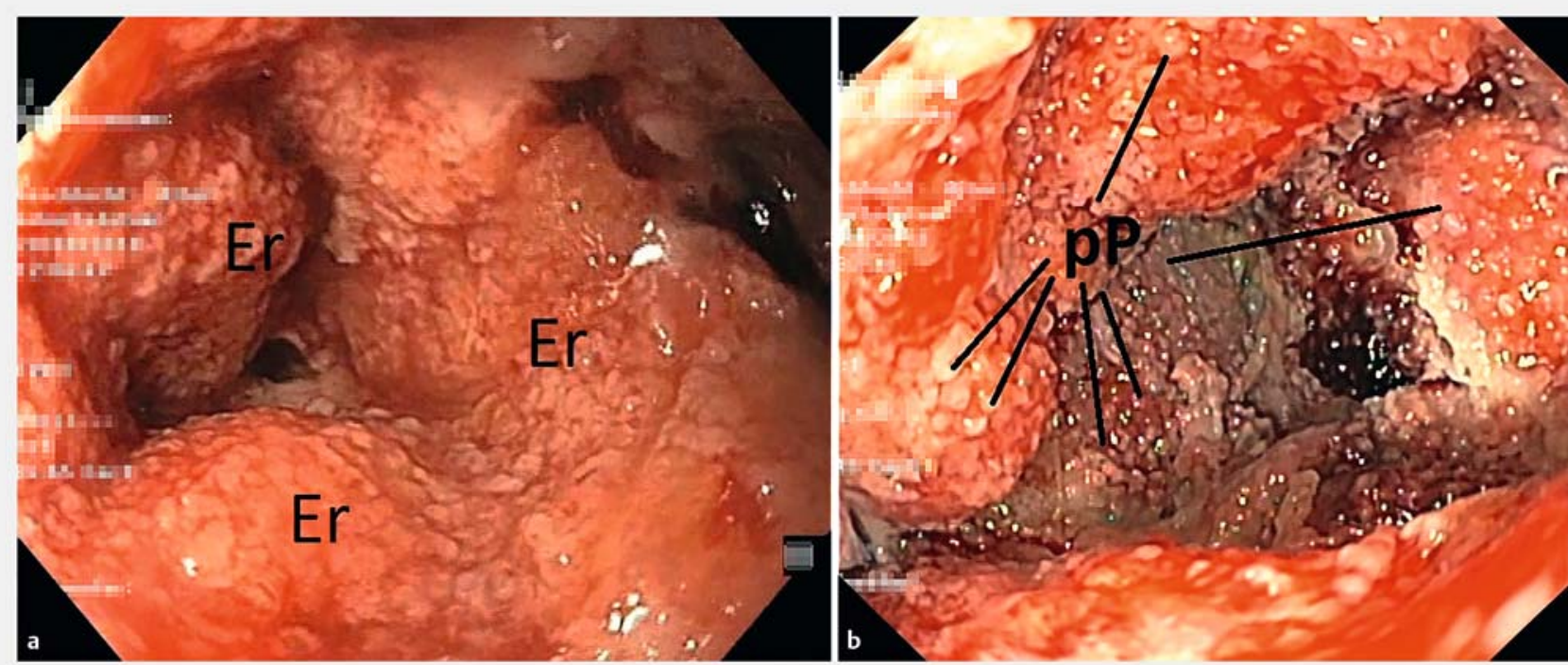

- Fig. 5 Wound surface after removing the open-pore element in the same patient. a After ENPT with polyurethane foam: irregular erosive pattern (Er). b After ENPT with film: regular pimpled pattern (pP).

The patient with iatrogenic perforation after ERCP was treated solely with OFD; a 20-cm-long film-oE was placed intraluminally onto the defect region for intraluminal ENPT. Three patients were treated with OFD and OPD. These patients had developed a duodenal cutaneous fistula along a surgical drain channel. Using the pull-through technique, ENPT was initiated with OPD (diameter: $15 \mathrm{~mm}$ ). During changing maneuvers, the diameter of the drainage was gradually reduced from $15 \mathrm{~mm}$ with OPD down to $4 \mathrm{~mm}$ with OFD. When OPD and OFD were placed via the pull-through technique, half the oE was inserted into the inner fistula opening and the other half was left in the duodenal lumen. Thus, these patients were treated with intraluminal and intracavitary variants of ENPT.

After 2 to 7 days the first change of sponge drainage was performed. In all patients the wound state had clearly improved. Necroses were debrided and replaced with granulation tissue ( $\triangleright$ Video). The size of the wound cavities was considerably reduced. In one patient the therapy could be stopped early after just one treatment cycle. In another patient, treated solely with a cavity created by suction during intracavitary ENPT, the OPD was left in place for 11 days without changing.

After intraluminal ENPT with OPD, a few superficial erosions of the duodenal mucosa were seen, which fully regressed within a few days after completion of therapy. When foam was placed on wound tissue, typical erosive patterns were found ( $\triangleright$ Fig.5a). For intraluminal use of OFD with film oE, no patterns were seen on the duodenal mucosa. When the OFD was inserted into a fistula channel, a typical pimpled suction pattern resulted ( $\boldsymbol{\vee}$ Fig. $\mathbf{5 b}$ ). No bleeding complications were observed.

ENPT was ended when the wound surface was reduced in size, covered with stable granulation tissue, and laboratory inflammation parameters were normalized. In patients with a duodenal cutaneous fistula, therapy ended when the channel had shrunk to $4 \mathrm{~mm}$ in diameter.

\section{Discussion}

Endoscopy in management of intestinal defects makes it possible to determine the important parameters of an intracorporal wound such as its perfusion, size, and location of the defect and allows an effective treatment at once.

The two most important treatment principles of ENPT in the duodenum are closure of the defect and drainage of secretions. Closure is achieved by occluding the intestinal lumen and covering the defect zone. Active permanent drainage of fluids is performed by continuous centripetal luminal suction. Immediately after starting ENPT, further contact of the intracorporal wound with aggressive digestive secretions is eliminated. These principles are essential surgical characteristics defined by Kirschner 1926 [23] for treatment of peritonitis (blocking the origin of infection and the elimination of exudate). Other beneficial factors associated with negative pressure therapy of surface wounds are promotion of granulation tissue, enhancement of perfusion, and reduction of inflammatory interstitial edema.

ENPT of the upper gastrointestinal tract was developed approximately 10 years ago and continues to evolve. Most studies of the technique have been performed using self-made openpore drains constructed with a polyurethane foam that is fixed at the distal end of a drainage tube. Also, there is currently no electronic negative pressure pump available that has been specifically developed as a medical device for ENPT. In any description of the latest technological developments and the broad and developing spectrum of use of ENPT, it is impossible to describe the technique without these modified materials and the off-label use of various components [24]. This means that in 
many cases of ENPT, no formal medical device safety information is given. Solutions must be jointly sought with partners in industry.

Since 2014, only one OPD device (EsoSPONGE B.Braun, Melsungen, Germany) has currently been approved for ENPT of the upper gastrointestinal tract and is commercially available in some parts of Europe. Its approval is limited to treatment of esophageal anastomotic leaks and perforations. Placement is performed along a $56-\mathrm{cm}$-long overtube using a pusher without direct visual endoscopic inspection. The duodenum cannot be reached with this device. Therefore, we had to develop alternative endoscopic techniques to insert OPD and OFD into the duodenum. Furthermore, when using ENPT in the esophagus, we prefer the technique of directly grasping the drainage with an endoscopic grasping instrument, inserting it into the esophagus via a short overtube and placing it under permanent endoscopic visual control [24].

Until now ENPT in the upper and lower gastrointestinal tract has been performed with OPDs [5, 25]. The advantage of using OPD is its adherence to the tissue to which suction is applied. The magnitude of adherence depends on pore size and quality of the tissue to which the vacuum is applied. A disadvantage of OPD is its diameter of more than $1.5 \mathrm{~cm}$. Insertion of the drainage tube to pass the pylorus can be difficult.

The advantage of the new OFD is its small diameter. Placement through small openings, fistula channels, and nasal insertion are more easily performed. OFD does not become as adherent to the tissue as OPD. Typical, regular pimpled patterns are found on wounds caused by the suction effect. These patterns disappear within a few days after drain removal. After intraluminal placement, few erosion patterns can be seen. If stable granulation tissue and a self-cleaning wound situation is ensured, ENPT can be stopped. The further healing process is monitored with endoscopy.

OPDs should not be placed in direct contact with blood vessels. Although no bleeding complications were seen, a certain risk of bleeding should be assumed for intracavitary ENPT. Due to the lower adhesion to tissue, we assume that film-based drains have a lower risk of bleeding than those based on polyurethane foam. It is for this reason that we start intracavitary treatment of the esophagus or rectum with OPD and then after the wound surface is clean - switch to the less adhesive film-based drains [24].

The double-layered film that is used in OFD has been developed for abdominal negative pressure therapy. This novel membrane can be placed directly on the peritoneum, intestines, and internal organs. Secretions are drained internally and through the space between the two layers of the film. In duodenal ENPT, we observed that active drainage of the duodenal secretions into the duodenal lumen may be the main reason for success. Both OPD and OFD can be used in drainage of fluids.

New surgical endoscopic strategies have been reported for closure of duodenal leaks with ENPT. In complicated anatomical situations, gastrostomies and jejunostomies were performed to insert OPD-drains along these artificial surgical openings [17, 18]. Furthermore, the pull-through technique simplifies placing and changing a drain in cases of duodenal cutaneous fistulas $[12,13,17]$.

Hochberger et al. used drainage of duodenal secretions with ENPT to prevent pancreatic enzyme-induced duodenal damage after large duodenal endoscopic resections [26]. To eliminate postoperative reflux after Ivor Lewis esophagectomy, our working group has started to eliminate gastroduodenal reflux with negative pressure immediately after the esophagectomy [27]. Therefore, we use a double-lumen OFD with an integrated intestinal feeding tube for simultaneous enteral nutrition [28]. Feisthammel et al. noted that if biliary secretions are completely drained, substitution with vitamin $\mathrm{K}$ might be required [14].

Most of our reported cases were treated due to postoperative complications. So far, we have not used primary ENPT to treat perforated peptic or duodenal ulcers. We have used ENPT for complex negative pressure therapy in one case of gastric perforation [29]. ENPT is an organ-preserving treatment; no resection procedures of the duodenum were necessary in our series.

We would like to mention potential limitations of this study. First, although relatively small, it is the largest study reporting use of ENPT in the duodenum. It has been demonstrated that the principle of open-pore negative pressure therapy also can be used in duodenal defects with a high success rate. These initial observations should be confirmed by other working groups. Therefore, we have summarized our ENPT methods in detail. Second, different drainage types were used for ENPT in the duodenum. They differed in the type of construction, open-pore material, and endoscopic placement techniques. An essential common feature of all the drains used is their open-pore design. This is necessary for directed discharge of the digestive secretions into the lumen. The multitude of available options makes a differentiated application of ENPT possible. The investigator is challenged to choose the method that is most suitable and to use it creatively. A standard recommendation for a single type of drain cannot yet be derived. Further studies describing the physical properties of open-pore materials and drainage types are needed to make therapeutic decisions based on scientific evidence. The same applies to the technical component of the electronic vacuum pump and its application to the wound tissue and the mucosa. Third, this was a retrospective observational study focusing on patients with postoperative duodenal leakages. Further studies are needed to describe the importance of the new therapy versus other measures. Until now, this therapy primarily has been used when surgery has been unsuccessful. Its early use may eliminate the need for invasive surgery. Furthermore, we assume that active drainage of digestive secretions with ENPT might also act as a prophylactic or preemptive treatment after interventional endoscopy or surgery of the duodenum.

\section{Conclusion}

ENPT is an innovative endoscopic alternative for treatment of duodenal defects. ENPT is an easy-to-use and effective technique in selected patients with duodenal leaks. 


\section{Acknowledgements}

The authors thank the nursing staff of the interdisciplinary endoscopic unit of "Marienkrankenhaus Hamburg" and of the "Westküstenklinikum Heide" for their excellent technical assistance. They also thank their colleagues from the intermediate care unit for their cooperation.

\section{Competing interests}

Dr. Loske is a consultant for Lohmann \& Rauscher GmbH \& Co.KG.

\section{References}

[1] Marshall JC, al Naqbi A. Principles of source control in the management of sepsis. Crit Care Clin 2009; 25: 753-768

[2] Bemelman WA, Baron TH. Endoscopic management of transmural defects, including leaks, perforations, and fistulae. Gastroenterology 2018; 154: 1938 - 1946.e1

[3] de Moura DTH, Sachdev AH, Thompson CC. Endoscopic full-thickness defects and closure techniques. Curr Treat Options Gastro 2018; 16: $386-405$

[4] Mennigen R, Senninger N, Laukoetter MG. Novel treatment options for perforations of the upper gastrointestinal tract: endoscopic vacuum therapy and over-the-scope clips. World J Gastroenterol 2014; 20: $7767-7776$

[5] Weidenhagen R, Gruetzner KU, Wiecken T et al. Endoscopic vacuumassisted closure of anastomotic leakage following anterior resection of the rectum: a new method. Surg Endosc 2008; 22: 1818-1825

[6] Loske G, Schorsch T, Muller C. Endoscopic vacuum sponge therapy for esophageal defects. Surg Endosc 2010; 24: 2531 - 2535

[7] Kuehn F, Loske G, Schiffmann L et al. Endoscopic vacuum therapy for various defects of the upper gastrointestinal tract. Surg Endosc 2017; 31: $3449-3458$

[8] Loske G, Schorsch T, Dahm C et al. latrogenic perforation of esophagus successfully treated with endoscopic vacuum therapy (EVT). Endosc Int Open 2015; 3: E547-E551

[9] Loske G, Schorsch T, Mueller CT. Endoscopic intraluminal vacuum therapy of duodenal perforation. Endoscopy 2010; 42: E109

[10] Loske G, Schorsch T. Intraluminal vacuum therapy - a new endoscopic Approach in the treatment of duodenal leakage. Endoskopie heute 2010; 23: 267-269

[11] Loske G, Rucktäschel F, Schorsch T et al. Successful endoscopic vacuum therapy with new open-pore film drainage in a case of iatrogenic duodenal perforation during ERCP. Endoscopy 2015; 47: E577E578

[12] Loske G, Liedke M, Schlöricke E et al. Endoscopic negative-pressure therapy for duodenal leakage using new open-pore film and polyurethane foam drains with the pull-through technique. Endoscopy 2017; 49: $\mathrm{E} 300-\mathrm{E} 302$
[13] Rucktaeschel F, Liedtke M, Schlöricke E et al. Gastroduodenal anastomotic insufficiency - pull-through technique for endoscopic negative pressure therapy with new types of open-pore drainages. Endoscopy 2019; 51: E85-E87

[14] Feisthammel J, Jonas S, Mössner J et al. The role of endoscopy in the therapy for perforations and leakages of the gastrointestinal tract. Zentralbl Chir 2013; 138: 295-300

[15] Pournaras DJ, Hardwick RH, Safranek PM et al. Endoluminal vacuum therapy (e-vac): a treatment option in oesophagogastric surgery. World J Surg 2018; 42: 2507-2511

[16] Yoo T, Hou LA, Reicher $S$ et al. Successful repair of duodenal perforation with endoscopic vacuum therapy. Gastrointest Endosc 2018; 87: $1363-1364$

[17] Glatz T, Fischer A, Hoeppner ] et al. Vacuum sponge therapy using the pull-through technique via a percutaneous endoscopic gastrostomy to treat iatrogenic duodenal perforation. Endoscopy 2015; 47: E567E568

[18] Kelm M, Seyfried F, Reimer S et al. Proximal jejunal stoma as ultima ratio in case of traumatic distal duodenal perforation facilitating successful EndoVAC ${ }^{\circledR}$ treatment: A case report. Int J Surg Case Rep 2017; 41: $401-403$

[19] Loske G, Schorsch T, Müller C. Intraluminal and intracavitary vacuum therapy for esophageal leakage: a new endoscopic minimally invasive approach. Endoscopy 2011; 43: 540 - 544

[20] Loske G, Schorsch T, Rucktaeschel F et al. Open-pore film drainage (OFD): a new multipurpose tool for endoscopic negative pressure therapy (ENPT). Endosc Int Open 2018; 6: E865-E871

[21] Wallstabe I, Tiedemann A, Schiefke I. Endoscopic vacuum-assisted therapy of infected pancreatic pseudocyst using a coated sponge. Endoscopy 2012; 44: E49-E50

[22] Loske G, Müller CT. Tips and tricks for endoscopic negative pressure therapy. Chirurg 2019; 90: 7

[23] Kirschner M. Die Behandlung der akuten eitrigen freien Bauchfellentzündung. Langenbecks Archiv Chirurgie 1926; 142: 253-263

[24] Fischer A, Thimme R, Hopt UT et al. Two-sided sponge (TSS) treatment: Description of a novel device and technique for endoscopic vacuum treatment (EVT) in the upper gastrointestinal tract. Endosc Int Open 2016; 4: E937-E940

[25] Loske G. Endoscopic negative pressure therapy of the upper gastrointestinal tract. Chirurg 2019; 90: 1

[26] Hochberger ], Wedi E, Tchoumak I et al. Over-the-scope clip placement and endosponge insertion for prevention of pancreatic enzymeinduced duodenal damage after large duodenal endoscopic resection. Endoscopy 2016; 48: E401 -E402

[27] Loske G, Schorsch T, Müller CT. Prevention of reflux after Ivor-Lewis esophagectomy with a new double-lumen open-pore film drainage (OFD) device. Innov Surg Sci 2018; 3: s15

[28] Loske G, Schorsch T, Müller CT. Prevention of reflux after esophagectomy with endoscopic negative pressure therapy using a new double-lumen open-pore film drainage with an intestinal feeding tube. Endoscopy 2017; 49: E294 -E295

[29] Loske G, Lang U, Schorsch T et al. Complex vacuum therapy of an abdominal abscess from gastric perforation: case report of innovative operative endoscopic management. Chirurg 2015; 86: 486-490 